\title{
TINJAUAN MADZHAB SHĀFI'I DAN MADZHAB HANBALI TENTANG HIAID YANG TERPUTUS-PUTUS SERTA AKIBAT HUKUMNYA
}

\author{
Farida Ulvi Na'imah \\ Institut Pesantren KH. Abdul Chalim Mojokerto \\ Email: faridaulvi@yahoo.com
}

\begin{abstract}
Many things open up opportunities for various interpretations of shari'ah contained in the Qur'an and as-Sunnah, including menstrual problems, especially in the case of intermittent menstruation. This study aims to explain the opinions and methods of the school of Sha fi' ${ }^{\prime}$ and $H$. anbali about the intermittent menstrual problem and its consequences. School of Sha fi' $i$ punishes naqa 'in the age of $n$ al-h aid as menstruation period. The method used is the legal method $b$ (leveling method), so that the legal consequences imposed are the inability to carry out worship during naqa', such as prayer, fasting, intercourse, $t$ awa $f$, $t$ alaq, calculation of iddah and silence at mosque. Whereas the school of law anbali believes that the cessation of blood (naqa') is punished sacred. This method is called the laqt method (acquisition). The legal consequences arising from the ability to carry out worship during naqa ${ }^{-}$, such as prayer, fasting, intercourse, $t$ awa $f$, $t$ alaq, calculation of iddah and silence in the mosque. This study concludes that the limitation of menstrual time is 10 days on average, so that in the span of 10 days if a blood break occurs, then the naqa according to the qaul as $s$ ah is to bathe jina bat and perform worship services) recommended, such as prayer, fasting and so forth.
\end{abstract}

Keywords: School of Sha fi ${ }^{\prime} \bar{i}$, School of Law Hanbali, Intermittent menstruation

\section{ABSTRAK}

Banyak hal yang membuka peluang terhadap berbagai penafsiran shari'ah yang terdapat dalam al-Qur'an dan as-Sunnah, termasuk di dalamnya masalah haid, khususnya pada masalah haid yang terputus-putus. Penelitian ini bertujuanu untuk menjelaskan pendapat dan metode dari madzhab Shafi' $\bar{i}$ dan Hanbali tentang masalah haid yang terputus-putus beserta akibat hukumannya. Madzhab Shäfi'i menghukumi naqà dalam zamān al-haid sebagai masa haid. Metode yang digunakan adalah metode sahb (metode penyamarataan), sehingga akibat hukum yang ditimbulkkan adalah ketidakbolehan melaksanakan ibadah pada masa naqa', seperti shalat, puasa, bersetubuh, tawä, talaq, perhitungan 'iddah dan berdiam diri di masjid. Sedangkan madzhab Hanbali berpendapat bahwa masa berhentinya darah (naqā') dihukumi suci. Metode ini disebut dengan metode laqt (perolehan). Akibat hukum yang ditimbulkan adalah kebolehan melaksanakan ibadah pada masa naqā', seperti shalat, puasa, bersetubuh, tawäf, talaq, perhitungan 'iddah dan berdiam diri di masjid. Penelitian ini menyimpulkan bhawa batasan lama waktu haid rata-rata adalah 10 hari, sehingga dalam rentang 10 hari jika terjadi putusnya darah, maka masa naqa'nya menurut qaul yang assah adalah melakukan mandi jinabat dan melakukan ibadah-ibadah yang dianjurkan, seperti shalat, puasa dan lain sebagainya.

Kata kunci : madzhab Shafi' $\bar{i}$, madzhab Hanbali, haid yang terputus-putus

\section{PENDAHULUAN}

Haid yang terputus-putus adalah pengalaman sebagian besar kaum wanita yang sudah mengalami haid. Pengalaman itu yang menimbulkan akibat hukum dalam berbagai masalah, oleh karena itu perlu dilakukan penelitian lebih lanjut. 
Haid secara etimologi berarti sesuatu yang mengalir. ${ }^{1}$ Sedangkan secara terminologi, haid merupakan darah yang mengalir dari pangkal Rahim wanita setelah umur baligh dalam keadaan sehat. ${ }^{2}$ Permasalahan haid sendiri khususnya haid yang terputus-putus tidak dijelaskan secara rinci dalam al-Qur'an an Hadith. Metode istinbät yang digunakan dalam masalah ini adalah berdasarkan istiqrā' (kesimpulan dari khusus ke umum) yang dilakukan oleh para imam madzhab seperti as-Shafi' $\bar{i}$. istiqra' asShäfi’i ini menghasilkan penetapan sekurang-kurangnya masa haid (akthar al-ḥaị̂) melalui research yang dilakukan as-Shäfi'i hanya pada wanita-wanita di negerinya dan pada zamannya.

Kaum wanita wajib belajar tentang hukum-hukum haid. Jika tidak, maka suami atau wali wanita tersebut, yang mengerti akan hukum haid wajib mengajarkan. Adapun jika suami tidak mengerti, maka suami tersebut harus mmengizinkan istrinya unntuk belajar kepada orang yang mengerti. Haram hukumnya bagi suami melarang istri yang tengah belajar ilmu haid, kecuali jika suami tersebut belajar kemudian mengajarkan kepada istri. ${ }^{3}$ Bahkan menurut ad-Dimyati, mengetahui hukum-hukum haid sama halnya mempelajari stengah lmu agama. ${ }^{4}$

Dalam permasalahan haid yang terputus darahnya, akan ditinjau dari dua madzhab haitu madzhab Shäfi’’ dan madzhab Hanbali, karena dua madzhab tersebut memiliki perbedaan pendapat yang cukup signifikan. Pendapat madzhab Shäfīi dikenal dengan metode $a s-S a h b$ (metode penyamarataan), ${ }^{5}$ yaitu metode yang menghitung masa bersih diantara masa haid dalam kurun waktu 15 hari sebagai bagian dari masa haid. Konsekuensinya adalah: apabila pada masa bersih dilakukan shalat, maka shalatnya tidak sah, tetapi wajib mengqạa. ketika melakukan puasa Ramaḍan, maka puasanya tidak sah dan wajib mengqaḍa karena masa tersbeut termasuk waktu haid. Metode $s a h b$ diwakili oleh mayoritas ulama madzhab Shäri ${ }^{\overline{1}}$. tokoh-tokohnya adalah ${ }^{6}$ ar-Rafi $^{\overline{1}} \bar{i}$ (w.

\footnotetext{
${ }^{1}$ Ahmad Warson Munawwir, al-Munawwir Kamus Arab-Indonesia (Surabaya: Pustaka Progresif, 1997), 314.

${ }^{2}$ Shams ad-Din Ibn 'Afi al-'Abbās ar-Ramli, Nihàyah al-Muhtaj, Juz (Kairo: Mustafa al-Bab Al-Halabi, 1938), 323.

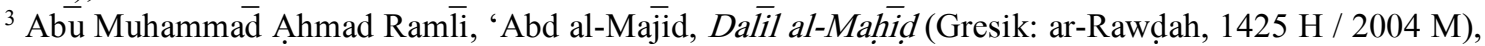
9.

${ }^{4}$ Abü Bakr Ibn as-Sayyid ad-Dimyạti, I'anah at-Tălibin, Juz 3 (Beirut: Dar al-Fikr, t.t), 214.

${ }^{5}$ Muhammad Ibn Ahmad a-Khatib as-Sharbini, Mugni al-Muhtaj, Juz (Kairo: t.p, t.t), 70.

${ }^{6}$ an-Nawawi, al-Majmū 'Ala Sharh al-Muhadzdzab, II (Damaskus: Dar al-Fikr, t.t), 501.
} 
$623 \mathrm{H}$ ) dalam kitab Fath al-Aziz bi Sharh al-Wajīz, an-Nawawi (w. $676 \mathrm{H}$ ) dalam kitab al-Majmū' ala Sharh at-Talkhịs, al-Ghazali (w. 505 H) dalam al-Khuläsah, al-Baghawi dan ar-Ruyyān dalam kitab al-Bahr. karena banyaknya ulama madzhab, tentu mereka memiliki pendapat yang beragam meskipun metode yang digunakan sama, yaitu metode $a s-S a h b$ (penyamarataan).

Sedangkan madzhab Ḥanbali disebut dengan metode al-laqt (metode temmuan) ${ }^{7}$ yaitu dengan menghitung waktu di mana kondisi haid darahnya keluar atau tidak, ketika masa keluar darah dihukumi haid, sedangkan dengan berhentinya darah (naqa') dihukumi suci. Tokoh-tokohnya seperti: ${ }^{8}$ al-Hajawi (w. 960 H) dalam kitabnya $Z \bar{a} d$ alMustaqna’ fi Ikhtịsār al-Muqanna', Manșūr Ibn Yūunus al-Bahūiti (w. 1051 H) dalam kitabnya Kasyf al-Qinā' 'an-Matn al-Iqnā', Ibn Qudamah (w. 620 H) dalam al-Mughni, dan Burhāan ad-Din Ibn Muflị (w. 884 H) dalam al-Mabda'.

Oleh karena itu, tujuan penelitian ini adalah menjelaskan pendapat dan metode dari madzhab Shäi’’ $\bar{i}$ dan madzhab Hanbali tentang masalah haị̣ yang terputus-putus beserta akibat hukum yang ditimbulkan dari kedua pendapat tersebut.

\section{PEMIKIRAN MADZHAB SHĀFI’̄I TENTANG HAID YANG TERPUTUS-PUTUS}

Dalam menjelaskan masalah haid yang terputus-utus, erat kaitannya mengetahui zamān al-haid terlebih dahulu. Masa minimal haid antara 24 jam (1 hari 1 malam). Umunya haid adalah 6 hari 6 malam atau 7 hari 7 malam, sedang paling lama waktu haid adalah 15 hari 15 malam (360 jam $)^{9}$. Jik akurang dari 24 jam makan tidak disbeut darah haid, begitu juga jika lebih drai 360 jam. Paling sedikitnya jarak waktu yang memisah antara satu haid dengan haid sebelumnya (aqal at-tuhṛ adalah 15 hari 15 malam.

Hal seperti ini dijelaskan as-Shinqiti bahwa dalam menyelesaikan masalah haid yang terputus-putus ini hendaknya memperhatikan kaidah aqal al-haid (masa minimal haid). Menurut ulama Shāfi’iyah dan Hanāabilah, batasan minimal yang disebut haid adalah sehari semalam. Contoh jika seseorang mengeluarkan darah setengah hari dan

\footnotetext{
${ }^{7}$ Ibn Hajar al-Haitami, Minhāj al-Qawìm, Juz I (t.t: t.p, t.t), 120.

${ }^{8}$ Burhan ad-Din Ibn Muflih, al-Mabda', Juz I (Riyadh: Dàr 'Ālim al-Jutub, 2003), 240.

${ }^{9} \mathrm{Abu}$ Zakariya, Muhyi ad-Din Ibn Sharaf an-Nawawi, al-Majmū' 'ala Sharh al-Muhadhdhab, Juz II (Damskus: Dar al-Fikr, t.t), 375. Lihat juga al-Hajawi, al-Iqnā' fi Fiqh al-Imām Ahmad Ibn Hanbal, Juz I (Beirat: Dar al-Ma'rifah, t.t), 65.
} 
suci sehari, maka darah tersebut belum bisa dihukumi darah haid, karena keluarnya darah kurang dari sehari semalam. ${ }^{10}$

Para ulama sepakat bahwa haid tidak disyaratkan darahnya keluar secara berkesinambungan pada masa haid itu, akan tetapi mereka berbeda pendapat tentang hukum maa-masa berhenti darah (naqa',) pada hari-hari haid. Ada du acara menyelesaikan masalah darah yang terputus-putus (ad-Dām al-Mutaqatta'), yaitu dengan metode sahb atau dengan metode laqt. ${ }^{11}$ Sedangan metode laqt, yaitu dengan menghitung waktu dimana kondisi haid darahnya keluar atau tidak, masa ketika keluar darah dihukumi haid, sedangkan masa berhentinya darah (naqa $\bar{a}$ ') dihukumi suci.

Dalam menyelesaikan permasalahan haid yag terputus-putus, madzhab Shäfīi cenderung menggunakan metode $s a h b$, seperti pendapat Ibrahim al-Bajuri bahwa paling sedikitnya haid ynag bersamaan dengan darah lainnya tidak bersambung, tetapi diselingi masa suci. ${ }^{12}$ Misalnya seorang wanita melihat darah beberapa waktu dan suci beberapa waktu. Semua itu dihitung haid dengan sharat tidak melewati 15 hari dan keluar waktu darahnya tidak kurang dari sedikitnya haid (24 jam). Ini disebut qaul al-Saḥb, karena mereka menarik hukum haid untuk waktu suci (naqā') dan semuanya mereka hukumi haid. As-Sharbini (w. $977 \mathrm{H}$ ) juga menjelaskan bahwa darah yang kurang dari masa minimal haid (1 hari / 24 jam), dan naqā' yang keluar antara dua haid serta memenuhi syarat-syarat maka kami menghukuminya haid dan ini disebut dengan qaul al-Sahb. ${ }^{13}$

Metode penyamarataan (sahḅ) merupakan metode menghitung masa bersih diantara masa haid dalam kurun waktu 15 hari sebagai bagian dari masa haid. ${ }^{14}$ Adapun ulama-ulama yang berafiliasi dalam qaul al-sahb seperti : ar-Rafi $\overline{\bar{i}}$ (w. $623 \mathrm{H}$ ), anNawawi (w. 676 H), az-Zarkashi (w. 794 H), Ibn Hajar al-Haitami (w. 974 H), Zakariya

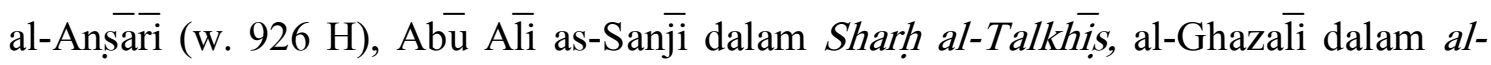
Khulāsah, al-Baghawi dan ar-Ruyyan dalam kitab al-Bahr. ${ }^{15}$ Paling sedikitnya jarak waktu yang memisah antara satu haid dengan haid sebelumnya (qaul at-tuhr) adalah 15

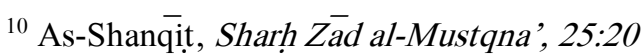

${ }^{11}$ Ibid.

${ }^{12}$ Ibrahim al-Bajuri, Hāasbiyah al-Bajuri, Juz I (t.t: D̄ar al-Ihȳà' al-'Arabiyah, t.ṭ, 110.

${ }^{13}$ Muhammad as-Sharbini al-Khatib, al-Iqnā' fi Hal Alfäd Abi Sujā', Juz I (Beirut: Dār al-Fikr, 1415 H), 98.

${ }^{14}$ Muhammad Ibn Ahmmad al-Khațib as-Sharbinini, Mugni al-Muhțaj, Juz $\overline{2}$ (Kairo: t.p, t.t), 70.

15 An-Nawawi, al-Majmū' 'Ala Sharh al-Muhadhdhab, II (Damaskus: Daar al-Fikr, t.t), 501.
} 
hari 15 malam. Jika masa pemisah kurang dari 15 hari, maka perinciannya sebagai berikut:

1. Bila darah pertama dan kedua masih dalam rangkaian 15 hari, terhitung dari permulaan haid pertama, maka semuanya dihukumi haid termasuk masa berhentinya darah (naq $\bar{a}$ '). Metode ini disebut dengan metode $s a h b$ (secara Bahasa berarti menyamaratakan), yaitu menghitung masa bersih diantara masa haid dalam kurun waktu 15 hari sebagai bagian dari masa haid. Adapaun dijadikannya hukum haid ketika naqa', ini dua syarat: ${ }^{16}$

a. Adanya naq $\bar{a}$ 'ini harus diantara dua haid dalam waktu 15 hari.

b. Kadar haidnya dlam 15 hari itu harus mencapai 24 jam.

Misal; keluar darah selama 3 hari. Berhenti (naqā') selama 3 hari. Kemudian keluar lagi selama hari. Maka, naqā'3 hari tersebut tetap dihukumi haid, sebab semuanya masih dalam masa-masa haid.

2. Bila darah kedua sudah keluar dari rangkaian masa 15 hari dari permulaan haid pertama, sementara masa pemisah ditambah darah pertama atau kedua tidak lebih dari 15 hari, maka darah kedua dihukumi darah fasad (kotor). ${ }^{17}$ Misal: keluar darah yang pertama 3 hari, berhenti selama 12 hari, kemudian keluar darah yang kedua selama 3 hari. Maka, darah yang keluar 3 hari pertama dihukumi haid, 12 hari tidak keluar darah dihukumi suci, dan darah yang kedua karena belum didahului minimal masa suci. 3 hari yang terakhir dianggap sebagai darah fasa $\bar{a}$, dikarenakan 3 hari yang terakhir digunakan untuk menyempurnakan naqa $\bar{a}$ ' 12 hari yang sebelumnya tetap dianggap suci yang belum genap 15 hari. $^{18}$

\section{DASAR PENGAMBILAN HUKUM HAID MADZHAB SHĀFI’I}

Permasalahan haid yang terputus-putus tidak dijelaskan dalam al-Qur'an dan hadith. Mengacu pada as-Shāê̄isebagai imam madzhab, maka metode istinbăt yang digunakan dalam masalah haid yang terput us-put us adalahh istiqra'mempelajari bagianbagiannya untuk mengetahui kondisi serta keistimewaannya. Dasar atas penetapan

\footnotetext{
16 as-Sharbīini, Mugni al-Muhtäj, II: 70.

${ }^{17}$ Hasan Bașri, al-Hawi, I, 389.

18 ibn Hajar al-Haitami, Fatawa al-Kubrā al-Fiqhiyah, Jilid I (Makkah: Dār al-Bäz, t.t), 86.
} 
sekurang-kurangnya masa haid (aqal al-ḥaị), umumnya masa haid (aghlab), dan sebanyak-banyaknya masa haid (akhtar al-haị) melalui istiqra' naqị (survey terbatas) karena research yang dilakukan as-Shäfi'i hanya pada wanita-wanita di negerinya dan pada zamannya, bahkan tidak pada wanita Arab secara keseluruhan. Hal ini seperti diungkapkan Ibrahīm al-Bajuri yng merupakan salah satu ulama madzhab Shäri $\overline{\text { i }}$ bahwa as-Shäī'i berkata :"yang menjadi dasar dan dijadikannya pegangan atas yang demikian adalah istiqra $\overline{\text {, }}$, tentang sedikitnya waktu haid, sebanyak-banyaknya waktu haid, serta umunya haid adalah hasil penelitian as-Shäfi’i terhadap wanita Arab, dan tidak mungkin as-Shäfi'i memeriksa seluruh wanita di seluruh alam sehingga pennelitian ini bisa disebut istiq $\bar{a}, \overline{t a m}$, bahkan seluruh wanita di negerinya pada zamannya, beliau melakukan penyelidikan atas sebagian wanita Arab sehingga terbiasa atas dugaan umunya hukum yaitu istiqra' naqis. sesungguhnya cara ini memang dapat memberikan faidah dugaan.

Masalah haid yang terput us-put us sendiri merupakan khilaf dikalangan ashäb asShä $\bar{a} \bar{i}$, karena pada masa as-Shafi' $\bar{i}$ sendiri belum diketemukan haid yang terputusput us. Khilâf itu bermula dari hasil istiqra' as-Shäfi' $\bar{i}$ bahwa aqal al-haid adalah 24 jam, aghlāab al-haid adalah 6/7 hari, dan Akhtar al-haid adalah 15 hari, sehingga ketika ada kasus golongan tersebut, golongan asha $\bar{b}$ terjadi khilaff. Sebagian berpendapat bahwa suci yang menyela-nyela haid terhitung haid, sebagian berendapat tetap suci, sebab faktanya tidak keluar darah dan jumlah seluruhnya tidak lebih dari 15 hari sebagai batas mustahạạah yang memiliki hukum khusus dalam praktiknya.

Dari sini dapat disimpulkan bahwa menurut pendapat madzhab Shäfi’i, jika dalam kurun waktu 15 hari keluar darah secara terputus-putus, maka terputusnya darah (naq $\bar{a}$ ') diantara dua hiad tetap dihukumi haid. Metode seperti ini dikenal dengan metode $s a h b$ (penyamarataan), karena masa berhentinya darah (naq $\bar{a}$ ') disamaratakan hukumnya sebagai haid.

\section{PEMIKIRAN MADZHAB HANBALII TENTNG HAID YANG TERPUTUS-PUTUS}

Adapun pendapat yang masyhur dikalangan madzhab Hanbali adalah, jika darah keluar berarti haid dan jika darah berhenti berarti suci, keucali apabila jumlah masanya melampaui batas maksimal masa haid yaitu 15 hari, maka darah yang keluar melampaui 
batas maksimal tersebut disebut darah istị̆ădah. Seperti pernyataan Șalih al-Uthaimin yang merupakan salah satu ulama madzhab Ḥanbali: ${ }^{19}$ Barang siapa sehari melihat darah, dan sehari berhenti darahnya (naqa','), maka ketika darah keluar dihukumi haid, dan masa naqā'-nya dihukumi suci. Misalnya seorang wanitta suau hari melihat darah ketika waktu maghrib, dan diwaktu maghrib berikutnya suci. Hukum berputar mengikuti 'illatnya, maka hari keluar darah dihukumi haid, sedabgkan hari berhentinya darah dihukumi suci".

Dari pernyataan di atas,hukum sesuatu itu didasarkan atas 'illat (alasan) dari sesuatu tersebut. Karena adanya darah maka dihukumi haid, dan masa tidaknya adanya darah (naq $\bar{a}$ ') dihukumi suci. Hal lain seperti diungkapkan as-Shinqiți bahwa: ${ }^{20}$ barang siapa melihat darah dan sehari kemudian naqa $\bar{a}$, misalkan hari pertama haid, hari kedua suci, hari ketiga haid, hari keempat suci, seperti itulah sampa 5 hari. Pendapat kedua ini disebut madzhab at-talfiq. Ini merupakan pendapat ulama madzhab Ḥanbali.

Menurut Ibn Qudamah al-Maqdisi, ketika seorang wanita sehari melihat darah dan sehari suci, maka pada masa suci wanita tersebut harus mandi dan sholat, seperti yang dikatakan 'Ibn Abbās; tidak boleh bagi wanita jika melihat suci hanya sesaat, kecuali jika wanita tersbeut sudah mandi dan darah terputus-putus kurang dari 15 hari, jika kurang dari 15 hari maka seluruhnya dihukumi haid dan mandinya setiap hari dan shalat jika sudah benar-benar suci. Jika melalui waktu 15 hari (melebihi zamān al-ḥaid) maka wanita tersebut termauk orang yang istihạa ${ }^{-} a{ }^{21}$ Atas dasar ini, berhentinya darah yang kurang dari satu hari buka merupakan kondisi suci, kecuali jika wanita tersebut mendapatkan bukti yang menunjukkan bahwa dia suci. Misalnya, berhenti darah tersbut terjadi pada akhir masa kebiasaan atau melihat lender putih.

\section{DASAR PENGAMBILAN HUKUM HAID MADZHAB ḤANBAL $\bar{I}$}

Dalam pengambilan hukum khususnya masalah haid, madzhab Ḥanbali juga menggunakan metode istiqrā', seperti halnya madzhab Shäri'i. Namun, bagi madzhab Hanbali istiqra', hanya diangga sebagai metode pengambilan dalil yang akan

\footnotetext{
${ }^{19}$ Muhammad Ibn Șaliḥ al-‘Uthaimin, as-Sharh al-Mumti', Juz I (t,t : Dar Ibn al-Jawzi, 1442 H), 500.

${ }^{20}$ Muhammad Ibn Muhammadd al-Mukhtāar as-Shinquiti, Sharh Zä́ al-Mustaqna', Juz 25 : 20.

${ }^{21}$ Muwaffiq ad-Din 'Abd Allah Ibn Qudamah al-Maqdisi, al-Kăfi fi al-Fiqh al-Imam Aḥmad Ibn Hanbal, Juz I (Beirut: Dār al-Kutb al-'Ilmiyah, t,t), 148.
} 
memberikan implikasi hukum general. Artinya, istiqrā' tidak lebih hanyalah upaya pengambilan dalil yang berfungsi mengeneraliasikan sebuah fakta. ${ }^{22}$

Dalam hal ini berbeda dengan madzhab Shäfi $\bar{i}$ yang menggunakan metode istiqra', sebagai penguat hukum, madzhab Ḥanbali memandang bahwa metode istiqrā, hanya sebagai sarana perwujudan hukum, karena tidak terdapat penjelasan secara rinci dalam al-Qur'an dan hadith.

Madzhab Shäfi'i menggunakan metode istiqrā' sebagai penguat hukum dengan melihat realita pada masyarakat, sehingga dalam konteks haid ditemukan masa minimal, maksimal dan umumnya haid, melihat kondisi diatas, rupa-rupanya madzhab Hanbali cenderung lebih menyukai penggunaan metode istidlal atau konklusi hukum yang kemudian secara langsung menarik kesimpulan dari paparan al-Qur’’an dan sunnah.

\section{STUDI PUSTAKA}

Sumber primer dalam pembahasan ini adalah kitab-kitab yang mengulas tentang pendapat ulama madzhab Shäfi'i seperti : ar-Rafi' $\bar{i}$ (w. 623 H) dalam kitabnya Fath al'Aziż bi Sharh al-Wajiz, an-Nawawi (w. 676 H) dalam kitabnya al-Majmū' 'ala Sharh alMuhadhadhab, Ibn Hajar al-Haitami dalam Minhāj al-Qawim, A $\overline{\overline{b u}}$ 'Ali as-Sanji dalam Sharh al-Talkhis, al-Ghazali, (w. 505 H) dalam al-Khuläsah, al-Baghawi dan ar-Ruyyān dalam kitab al-Baḥr serta sumber primer dari madhzab Hanbali seperti: al-Hajawi (w. 960 H) dalam Zād al-Mustaqna’ fi Ikhtịsār al-Muqana', Manșūr Ibn Yūunus al-Bahūiti (w. 1051 H) dalam kitabnya Kasyf al-Qinā' 'an Matn al-Iqnā', Ibn Qudāmah (w. 620 H) dalam al-Mugnī, dan Burhān ad-Din Ibn Muflị (w. 884 H) dalam al-Mabda'.

Sumber data sekunder merupakan pendapat para pakar yang mendukung tema pembahasan atau tidak secara langsung berhubungan namun ada kesamaan tema yang dikembangkan, dalam hal ini literatur yang dipakai adalah Mugni al-Muhtaj karangan Khậīb as-Sharini, Hashiyah as-Sharwani karangan 'Abd al-Majid as-Sharwani, dan lainlain.

Sumber data tersier yang digunakan dalam penelitian ini adalah kamus alMunawwir, artikel-artikel, jurnal, dan juga data dari internet yang memiliki relevansi dengan masalah penelitian.

${ }^{22}$ Muhammad Sulaimān Ibn 'Abd Allāh al-Ashqar, al-Wa dịh (Amman; Dār al-Fath, 1992), 157. 


\section{METODOLOGI}

Jenis penelitian in termasuk penelitian pustaka (library research), yakni dengan mengacu serta menelaah data-data ilmiah berupa kitab-kitab klasik dan modern serta buku-buku yang berhubungan dengan permasalahan haid. Sedangkan analisis yang digunakan dalam penelitian ini adalah content analysis (analisa isi) agar diperoleh suatu pemahaman yang akurat.

\section{ANALISIS, HASIL DAN DISKUSI}

Dari pemikiran madzhab Shăfi’’ dan madzhab Hanbali, tentang haid yang terput us-putus, maka menghasilkan akibat hukum yang berbeda terhadap masalah shalat, puaa, persetubuhan, tawaf, talā, perhitungan masa 'iddah, menyentuh dan membaca alQur'an serta berdiam diri di masjid. Hal ini dapat diuraikan sebagai berikut:

1. para ulama sepakat atas keharaman shalat baik fard maupun sunnah bagi perempuan had. An-Nawawi mengatakan: ${ }^{23}$ "Mereka sepakat atas gugurnya kewajiban shalat bagi orang haid dan mereka sepakat pula bahwa mengqada shalat yang ia tinggalkan pada masa haid tidak wajib menggantikannya".

2. Untuk puasa wajib yang ditinggalkan ketika haid, maka harus di-qada, sementara untuk shalat yang ditinggalkan tidak harus di-qada, sebab hal ini akan memberatkan wanita tersbut dalam kondisi lemah karena keluarnya darah dari dalam tubuhnya. Belum lagii gangguan psikis dan fisik yang mengiri selama masa haid. Sementara itu, ibadah puasa juga menyebabkan kondisi tubuh menjadi lemah. Bila wanita haid tetap diwajibkan berpuasa, akan angat memberatkan kondisi wanita tersebut. Secara logis, itulah kira-kira mengapa puasa tidak dibebankan keada wanita yang sedang haid. ${ }^{24}$

3. Untuk bersetubuh saath haid, diharamkan bagi seorang suami menggauli istrinya sampai dia benar-benar dalam keadaan suci. Diharamkan pula nagi sang istri memberi kesempatan kepada suami untuk melakukan hal tersebut. Adapun dalam pemaknaan suci para ulama berbeda pendapat sebagai berikut; menurut $\mathrm{Abu}$

\footnotetext{
${ }^{23}$ An-Nawawi, al-Majmū', II: 503.

${ }^{24}$ Lissa Malike dan Asmawati, Haid Membawa Berkah, (Jakarta: Niaga Swadaya, 2010), 57-58.
} 
Ḥanifah, suci bermakna berhentinya darah. ${ }^{25}$ Sehingga konsekuensinya, seorang suami boleh bersetubuh dengan istrinya setelah darah berhenti keluar, meskipun belum mandi jinābat. Sedangkan menurut Jumh $\bar{u} r$ ulama, yaitu as-Shafì' $\bar{i}, \overline{M a}$ lik, dan Ibn Hạbal, suci ditandai dengan mandi jinăbat. ${ }^{26}$ Adapun bersenang-senang dengan istrinya masih diperbolehkan selama tidak sampai bersetubuh. Meskipun diperbolehkan melakukan istimta' (bersenang-senang), namun hal seperti ini dimungkinkan dapat mengantarkan pelakunya melakukan jimáa', sehingga jika mengikuti kaidah sadd ad-dara'̄i (mencegah terjadinya bahaya), maka menjauhinya adalah lebih baik. Menurut as-Sha'rawi alasan lain yang mendasari larangan untuk melakukan hubungan intim saat haid antara lain karena alasan kesehatan. ${ }^{27}$ Beliau menegaskan, bahwa bagi laki-laki, darah haid bisa menyebabkan masuknya bakteri penyakit ke dalam tubuh melalui kemaluan wanita.

4. Hukum tala $q$ adalah mubah. Namun, tala $q$ itu termasuk perbuatan yang tidak disenangi Nabi. Hal itu mengandung arti perceraian itu hukumnya makrūh. tala $\bar{q}$ hanya boleh dilakukan dalam keadaan mendesak. Meskipun dalam keadaan mendesak, tala $\bar{q}$ tidak boleh dijatuhkan sembarang waktu. Syari'at memperbolehkan suami menjatuhkan . tala $q$ terhadap istri ketika sedang suci dari haid. Sementara itu, seorang suami haram melakukan tala $q$ terhadap istrinya dalam keadaan haid. Hal ini sesuai dengan firman Allah: ${ }^{28}$

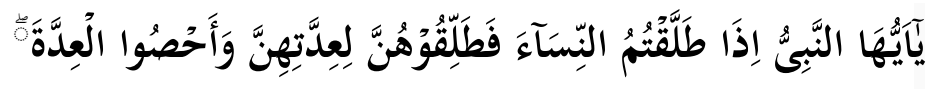

"Hai Nabi, apabila kamu menceraikan istri-istrimu maka hendaklah kamu ceraikan mereka pada waktu mereka dapat (menghadapi) 'iddah-nya (yang wajar)".

Menceraikan istri semasa haid, menyebabkan istri tidak mendapatkan 'iddah-nya secara wajar. Bila istri diceraikan semasa haid, maka sisa waktu haid belum bisa dimulai perhitungan masa 'iddah. ${ }^{29} \mathrm{Hal}$ ini dilarang, karena bisa memperpanjang waktu 'iddah istri, karena harus menunggu sampai istri tersebut suci kemudian

\footnotetext{
${ }^{25}$ Ali as-Ṣabuni, Tafsir Ayat al-Ahkam, Juz I (Beirut: Darr al-Fikr, t.t), 301.

${ }^{26} \mathrm{Ibid}$

${ }^{27}$ Muhammad Mutawalli as-Sha'rawi, Fiqh Wnanita, (Jakarta: Pena, 2005), 25.

${ }^{28}$ al-Qur'an, 65 (at-Ṭalaq): I

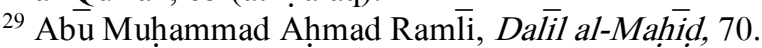


haid kembali, baru perhitungan 'iddah dimulai. Namun, jika suami menjatuhkan talaq ketika istri dalam keadaan suci, maka saat itu pula sudah bisa dimulai perhitungan 'iddah bagi istri, sehingga waktu 'iddah yang dijalani istri tidak terlalu lama. Diharamkan juga men-talā istri yang sedang suci tetapi sudah disetubuhi, karena bisa jadi persetubuhan tersebut mengakibatkan kehamilan.

5. Sesuai dengan pembahasan haid, maka 'iddah yang akan dibahas adalah 'iddah perempuan yang sedang haid, yaitu tiga kali quru', hal ini berdasarkan pada firman Allah SWT. yang artinya: ${ }^{30}$ "Wanita-wanita yang ditalak hendaklah menahan diri (mnunggu) tiga kali qurū'. Tidak boleh mereka menyembunyikan apa yang diciptakan Allah dalam rahimnya, jika mereka beriman kepada Allah dan hari akhirat. Dan suami-suaminya berhak merujuknya dalam masa menanti itu, jika mereka (para suami) itu menghendki ishlah. Dan para wanita mempunyai hak yang seimbang dengan kewajibannya menurut cara yang ma'ruf. Namun para suami mempunyai satu tingkatan kelebihan daripada istrinya. Dan Allah Maha Perkasa Lagi Maha Bijaksana”.

Yang menjadi persoalan di sini adalah pengertian qurū' yang mushtarak, yaitu mengandung arti lebi dari satu. Kadang diartikan "ath-tuhr"(suci) dan kadangkadang-kadang diartikan pula al-haydah (haid). Masing-masing dari arti lafad quru' 'ini menghasilkan deduksi hukum yang berbeda.

As-Shäfi'i, berpendapat bahwa qurū' bermakna tuhr (suci), hal ini didasarkan atas teori 'adad-ma'dūd. Lafaz qurū'merupakan isim 'adad, dimana jika 'adadnya (lafą thalathah) menunjukkan mu'annath, maka ma'dūd-nya (yang terbilang) yaitu lafaz quru $\bar{u}$, harus menunjukkan mudakar. Dari sini dapat disimpulkan, bahwa qurū bermakna suci (tuhr karena menunjukkan nama mudakar. ${ }^{31}$ Lafaz qurū' bermakna suci (tuhr) disepakati oleh fuqahā' Mesir, as-

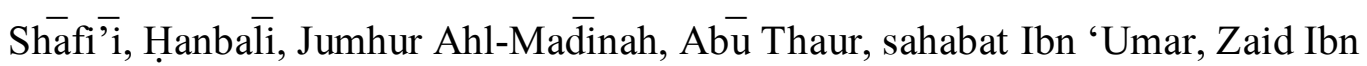
Thabit, dan $\overline{\mathrm{A}}$ 'ishah. ${ }^{32}$

\footnotetext{
${ }^{30} \mathrm{Al}-\mathrm{Qur}{ }^{-}$an, 2 (al-Baqarah): 228.

31 'Abd al-Wahhab Khalaf, 'Ilm Usül al-Fiqh (Mesir: Dār al-Qalam, 1978), 172.

${ }^{32}$ Ibn Rushd al-Andalusi, Bida,yah al-Mujathid wa Hihayah al-Muqtasid, Juz II (Jakarta: Där al-Ihyaa' alKutub al-'Arabiyah, 67.
} 
Sedangkan Abū Hanifah berpendapat bahwa qur $\bar{u}$ ' bermakna haid. Hal ini didasarkan atas pendapat bahwa kebersihan rahi, (bara' at ar-rạmm) hanya bisa diketahui dengan haid, tidak dengn suci. ${ }^{33}$ Quru' bermakna haid disepakati oleh

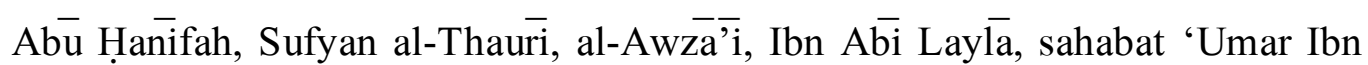
Khațtab, Ibn Mas'ud, dan Ali Ibn Abi, Ṭāib. ${ }^{34}$

Dari penjelasan diatas, peneliti memakai pendapat jumhur, bahwa qur $\bar{u}$, bermakna suci. Meskipun akibat hukum antara pendapat madzhab Shäfi’i (qaul as-sahb) dan madzhab Hanbāi (qaul al-laqt) memiliki perbedaan yang cukup signifikan, namun dalam permasalahan perhitungan 'iddah kedua pendapat in selaras dan tidak bertentangan. Perhitungan 'iddah 3 kali suci maksudnya setelah 3 daur, dimana 1 daur adalah 1 kali minimal suci (15 hari) +1 kali minimal haid (1 hari 1 malam $/ 24$ jam $)=16$ hari. Maka, dalam kasus haid yang terput us-put us, ketika masa naqā', (darah berhenti keluar) pada hari-hari haid, belum bia dimulai perhitungan 'iddah, karena perhitungan 'iddah baru bisa dimulai setelah suci mutlak.

6. Membaca dan Menyentuh al-Qur'an

Sebagaian ulama berpendapat bahwa wanita yang haid dilarang untuk membaca al-Qur'an (dengan hafalannya). Di sisi lain, Abū Bakr as-Shatāa ad-Dimyatīi yang merupakan salah seorang ulama madzhab Shafi' $\bar{\prime}$ i memperbolehkan membaca alQur'an bagi orang haid dan junub asalkan dengan niat berdzikir. ${ }^{35}$ beliau menjelaskan bahwa haram membaca al-Qur'an (niat bertujuan membaca alQur’an) bagi orang yang junub, kecuali jika tidak ada niat membacanya, seperti niat dzikir, ceramah-ceramah yang mengandung ayat al-Qur'an, cerita yang kebetulan cocok denga nisi al-Qur'an atau niat menghafal. Begitu juga tidak haramjika memutlakkannya, artinya mengucapkannya pada lisan tanpa bertujuan apa-apa.

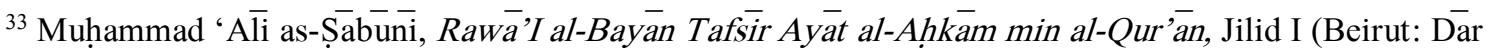
al-Fikr, t.t), 329.

${ }^{34}$ Ibn Rushd, Bidayah al-Mujtahid, II: 67.

${ }^{35}$ Abu Bark as-Shată, I'anah at-Tăalibin (Indonesia : Dar-Ihyä, t.t), 69.
} 
Begitu juga dalam kitab Jawāhir al-Bukhari disebutkan bahwa bagi orang yang haid atau junub diperbolehkan membaca al-Qur'an asalkan dengan niat dzikir mutlak (khususnya bagi orang yang hal al-Qur'an).

Demikian halnya dalam kitab Sharh Umdah al-Ahkam, para ulama memperbolehkan bagi para penghafal al-Qur'an untuk menjaga hafalannya dengan terus melafadkan al-Qur'an meskipun sedang haid dan junub, karen ajika tidak begitu dikhawatirkan akan hilang hafalannya. Namun dalam dalil ini, membaca al-Qur'an tetap diperbolehkan tetapi memegang mushaf al-Qur'an tidak diperbolehkan. ${ }^{36}$

Adapun permasalahan tidak bolehnya menyentuh mushaf bagi orang yang berhadath adalah pendapat mayoritas fuqaha', dan ulama' yang memperbolehkanya terbatas dalam keadaan darurat seperti kegiatan belajar mengajar. Adapun bagi orang yang berhadath seperti junub, haid, nifas haram untuk menyentuh mushaf karen atidaj adanya kesucian.

7. Berdiam diri di Masjid

Sebagian ulama melarang seseorang yang haid dan junub untuk masuk dn berdiam diri di masjid, namun ketika sesseorang berhajat hendak mengambil barangnya yang tertinggal di masjid maialnya atau hanya lewat melintas maka hal tersebut diperbolehkan. ${ }^{37}$

Menurut $q a u p^{\beta 8}$ asah (pendapat yang lebih sah) dari kalangan madzhab Shafí $\bar{i}$ yang berafiliasi terhadap qaul $a s-s a h b^{39}$ jika diketahui pada hari pertama haid selama 24 jam, dan pada hari kedua naqa', maka diharuskan mandi dan diperbolehkan melaksanakan amalan-amalan ketika suci seperti puasa, shalat, tawaf, membaca al-Qur’an, menyentuh muṣhaf, dan sebagainya, meskipun pada kenyataannya keluar darah lagi pada hari berikutnya selama masih berada pada zamān al-haị. Langkah bersuci tersbeut diambil berdasarkan asumsi (perkiraan)

\footnotetext{
${ }^{36}$ Ibn Jibrin, Sharh Umdah al-Ahkām, VII: 15.

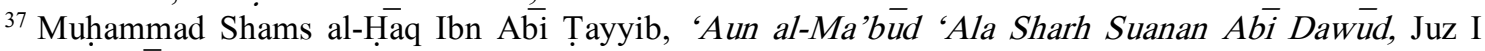
(Beirut: Dar al-Kutub al-'Ilmiyah, $1415 \mathrm{H}), 269$.

${ }^{38}$ Qaul Sha, $\overline{\text { fi }}$ 'iyang berafiliasi pada qaul as-Sahb terbagi atas qaul assah dan qaul laqt.

${ }^{39}$ Madzhab Shafi' ${ }^{\prime}$ terbagi atas qaul asah (pendapat yang lebih sah) dan qaul da'̄if (pendapat yang lemah).
} 
sebagai langkah ihtiyạt bnetuk kehati-hatian meskipun pada akhirnya jika diketahui keluar darah lagi, ibadah-ibadah tersbeut dianggap batal. ${ }^{40}$

Sedangkan menurut qaul da' $\bar{i} f$ (pendapat yang lemah) dari madzhab Shäfì'i, tidak perlu terburut-buru melakukan shalat sebelum menunggu suci mutlak, karena ibadah yang akan dilakukan pada masa naqā' tersebut dianggap sia-sia / batal, sehingga diperbolehkan menunggu (tidak bersuci dahulu dan tidak melakukan ibadah apapun) sampai benar-benar suci mutlak. ${ }^{41}$

Haid yang dinyatakan berhenti jika kemaluannya betul-betul sudah bersih. Untuk mengetahui haid sudah berhenti mutlak ialah, andaikan kapas putih dimasukkan kedalam farji sudah tidak ada basahnya darah walaupun ada bagian farji yang tidak wajib di basuh waktu bersuci ${ }^{42}$ atau ketika diusap dengan kapas, sudah tidak ada cairan yang sesuai dengan sifat dan warna darah (hanya berupa cairan bening). Namun, bila masih ada cairan yang berwarna keruh dan kuning, terjadi khilaf diantara para ulama. Menurut Jumhur, warna tersebut masih dihukumi darah haid, karena menganggap masih berwarna darah. ${ }^{43}$ Sebagian lain menyebutkan warna tersebut bukan darah haid, karena menganggap warna tersebut tidak berwarna darah. ${ }^{44} \mathrm{Jika}$ ternyata darah yang keluar selama beberapa hari tidak encapai 24 jam / 1 hari 1 malam, maka darah tersebut dihukumi darah fasad, ${ }^{45}$ dan wanita tersebut wajib mengganti shalat sejumlah hari yang ditinggalkan.

Meskipun madzhab Shäfi’i terbagi menjadi dua pendapat, tetapi pada intinya kesimpulan hukum yang dihasilkan dalam masalah haid yang terputus-putus adalah sama yaitu, ketika masa terputusnya darah (naqā') dihukumi haid.

\footnotetext{
${ }^{40}$ Pendapat ini merupakan pendapat yang lebih sah. Lihat dalam an-Nawawi, al-Majmū, II: 502-503.Ibid., II:503

${ }^{41}$ Hal ini merupakan pendapat madzhab Shäfi'i yang da ${ }^{\bar{\prime}}$ if. Lihat Ibid.

${ }^{42}$ Ibn Hajar al-Haitami, Tuhfah al-Muhtaj, IV: 254.

${ }^{43}$ Warna darah haid tidak harus berwarna merah, dan darah berwarna merah juga belum tentu darah haid. Karena menghukumi darah itu disebut darah haid ada beberapa syarat-syarat, yaitu memahami darah haid harus memahami warna sifat, dan waktu lamanya mengeluarka darah. Adapun warna darah antara lain ; Merah kehitam-hitaman, merah, merah kekuning-kuningan, kuning, kuning keputih-putihan (krem keruh). Sedangkan sifat darah antara lain kental, cair, bau anyir menyengat, dan bau anyir tidak menyengat. Lihat dalam Saifuddin Zuhri, Haid dan Problematika Wanita (Mojokerto: Majma’ al-Bahrain, 2010), 35.

${ }^{44}$ As-Sharbini, Mughni al-Muhtaj, I: 113.

45 Ad-Dimyati, I'anah at-Tăìibin, I: 72.
} 
Sedanngkan menurut madzhab Ḥanbali yang condong terhadap qaul al-laqt, masa naqā' dalam haid tersebut boleh melakukan shalat, karena masa naqa'-nya dihukumi suci. Tetapi dalam praktiknya tetap mandi terlebih dahulu, seperti orang suci pada umumnya. ${ }^{46}$ Ibadah-ibadah yang dilakukan pada masa naqa, dianggap sudah sah, sehingga tidak perlu diqada' meskipun beberapa hari kemudian diketahui keluar darah lagi selama masih dalam zamān al-haid. Jika ternyata selama beberapa hari darah yang keluar tersebut jumlahnya tidak mencapai 24 jam / 1 hari 1 malam, maka darah tersebut dihukumi fasad $^{47}$ dan wanita tersebut harus mengganti shalat yang dtitinggalkan hanya dengan membersihkan farjinya saja (tanpa mandi jinābat), tetapi yang disunnahkan adalah mandi. ${ }^{48}$ Keunggulan qaul as-sahb, serta intensitas beribadahnya juga lebih banyak.

Dari dua perbedaan pendapatt di atas (madzhab Shäfi'i yang condong kepada qaul as-sạhb dan Ḥanbali yang condong kepada qaul al-laqt), peneliti mengambil jalan tengah untuk keduanya. Erat kaitannya masalah haid dihubungkan dengan lama waktu, hal ini juga disepakati madzhab Shäfīi dan Hanbali. Mereka menentukan masa haid pali sedikit (aqal al-tuhr) adalah sehari semalam (24 jam) baik terjadi secara terus menerus dalam satu hari, atau dalam rentang waktu maksimal 15 hari namun keluarnya secara terputus-putus. Masa paling lama (Akhtar al-haid) kedua madzhab juga menyepakati 15 hari. Namun yang membedakan keduanya hanya perlakukan terhadap naq $\bar{a}$, ketika masa terput usnya darah dalam rentang waktu 15 hari.

Penelitian yang dilakukan kedua imam madzhab tersebut berada dikawasan jazirah arab yang secara geografi dan topografi berbeda dengan orang Indonesia. Sumber nutrisi yang diterima kedua wilayah tersebut juga berbeda sehingga diperkirakan juga kaan mempengaruhi lama haid. Hal ini yang menurut penulis perlu melakukan penelitian ulang terhadap sejumlah wanita Indonesia yang erat hubungannya dengan masalah haid. Penelitian ini penulis lakukan terhadap 100

\footnotetext{
${ }^{46}$ Ibn Qudāmah al-Maqdisi, al-Käfi fi Fiqh Ibn Hanbal, Juz I (t.t:t.p, t:t), 113.

${ }^{47}$ Darah fasad adalah darah rusak. Adapun hukumnya sama seperti darah istihădah.

${ }^{48}$ Ibn Șaalih al-Uthaimin, as-Sharh al-Mumti', I: 500.
} 
orang yang diperkirakan bisa mewakili orang wanita pada umumnya. ${ }^{49}$ Hasilnya ditemukan bahwa umumnya waktu haid adalah 708 hari. Masa paling lama haid adalah 10-12 hari.

Dari sini penulis menyimpulkan bahwa batasan lama waktu haid adalah 10 hari, sehingga dalam rentang 10 ari jika terjadi put usnya darah, maka masa naq $\bar{a}$ '-nya lebih baik melakukan mandi jinābat dan melakukan ibadah-ibadah yang dianjurkan, seperti shalat, dan puasa. Adapun diterima atau tidaknya ibadah yang kita lakukan pada masa naqā' haid adalah semata-mata urusan Allah. Langkah ini juga merupakan langkah hati-hati (ịtiyạt) dalam mengaplikasikan sebuah hukum. Keunggulan lainnya adallah intensitas ibadah yang dilakukan juga lebih banyak disbanding jika kita menunggu sampai 15 hari sampai terbukti mengalami suci secara mutlak.

\section{KESIMPULAN}

Dari beberapa uraian diatas dapat disimpulkan bahwa : Pendapat madzhab Shäri’’ tentang darah haid yang terputus-putus yaitu menghukumi masa naqā' dalam zamān al-haid sebagai haid. Metode yang digunakan adalah metode sahb (metode penyamarataan), karena masa terputusnya darah disamaratakan hukumnya sebagai haid. Pendapat madzhab Shāâì sendiri terbagi atas dua, yaitu qaul ạsah (yang lebih sah) dan

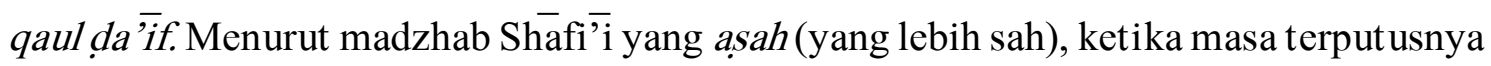
darah (naq $\bar{a}$ ) dihukumi haid, tetapi setiap masa naq $\bar{a}$, dianjurkan mandi jinābat dan melakukan ibadah seperti yang biasa dilakukan orang suci seperti shalat, puasa, tawä, kecuali bersetubuh. Pendapat ini yang erat hubungannya sangat mennjaga sistem produki wanita, karena oada masa naqā' masih terjadi percampuran antara darh bersih dan darah kotor. Adapun jika diketahui darah keluar lagi kemudian hari maka ibadahibadah tersebut dianggap batal (tidak sah). Sedangkan menurut madzhab Shāfì yang da'if , masa naq $\bar{a}$ ' tidak perlu terburu-buru melakukan ibadah-ibadah seperti puasa,

\footnotetext{
${ }^{49}$ Objek penelitian adalah santri PP. Al-Hidayah, Ketegan, Tanggulangin, Sidoarjo, penelitian dilakukan pada 100 santri yang sudah mengalami haid berkali-kali. Penelitian dilakukan pada hari Ahad, tanggal 26 Juni 2011.
} 
shalat karena pada hari-hari tersebut ibadah yang dilakukan terhitung batal sebelum suci mutlak.

Menurut madzhab Ḥanbali, masa berhentinya darah (naq $\bar{a}$ ) dihukumi suci. Metode ini disebut dengan metode laqt (perolehan). Dinamakan demikian karena ketika terlihat (memperoleh) darah dihukumi haid, ketika darah terput us (naq $\bar{a}$ ) dihukumi suci. Qaul ini disebut juga talfiq (secara Bahasa adalah mencampur, karena dalam qaul ini dalam waktu 15 hari atau kurang, bisa terjadi percampuran antara hari haid dan suci secara silih berganti). Menurut madzhab Ḥanbali, waktu naqa $\bar{a}$ ' dalam haid tersebu boleh melakukan shalat, puasa, persetubuhan, tawăf , talaq, membaca dan menyentuh alQur'an dan masuk masjid, karena masa naq $\bar{a}$, nya dihukumi suci. Tetapi dalam praktiknya tetap mandi terlebih dahulu, seperti orang suci pada umumnya.

Peneliti sendiri menyimmpulkan bahwa batasan lama waktu haid pada umumnya adalah 10 hari, sehingga dalam rentang 10 hari jika terjadi putusnya darah, maka masa naqā' nya lebih baik melakukan mandi jinābat dan melakukan ibadah-ibadah yang dianjurkan, seperti shalat dan puasa.

\section{DAFTAR PUSTAKA}

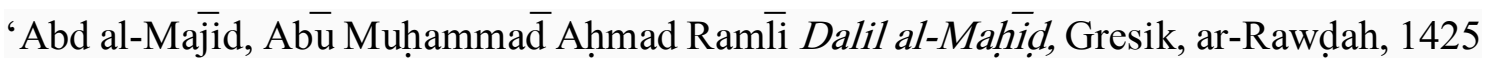
$\mathrm{H} / 2004 \mathrm{M}$

al-Ashqar, Muhammad Sulaimān Ibn 'Abd Allāh, al-Wad̄ịh, Amman: Dār al-Fath, 1992. al-Bahūti, Manșūr Ibn Yūunus Kashf al-Qinā' 'an Matn al-Iqnā', Mesir: t.p, t.t. al-Bajüri, Hāshiyah al-Bajuri 'ala Ibn al-Qasim, Semarang, Toha Putera, t.t. al-Bașri, Abū Ḥasan 'Ali Ibn Mụammad Ibn Ḥabib al-Baghdadi, al-Ḥawi fi Fiqh asShāafi $\bar{i}$, Mesir: Dār al-Kutub al-'Ilmiyah, 1994.

Departemen Agama RI, al-Qur'an dan Terjemahannya, Semarang, Toha Putera, 1995. ad-Dimyāti, Abū Bakr Ibn as-Sayyid, I'annah at-Tălibin, Juz 3, Beirut; Dār al-Fikr, t.t. al-Haitami, Ibn Hajar, Minhāj al-Qawìm, t.t, t.p, t.t.

, Fatäwā al-Kubrā al-Fiqhiyah, Makkah: Dār al-Bäz, t.t.

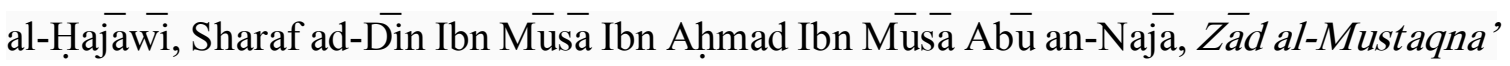

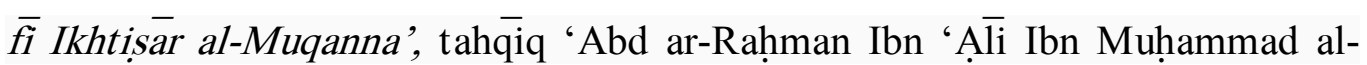
'Assakir, Riyad, Dār Watāan li an-Nashr, t.t. 
, al-Iqnā' fi Fiqh al-Imām Ahmad Ibn Hanbal, Beirut: Dar al-Ma'rifah, t.t.

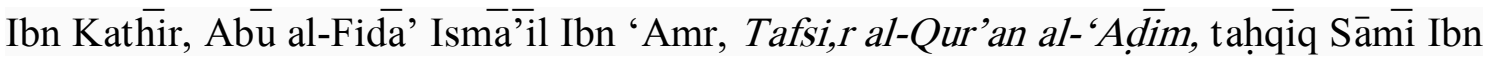
Muhammad Salamah, t.t: Dār Tayyibah, 1999.

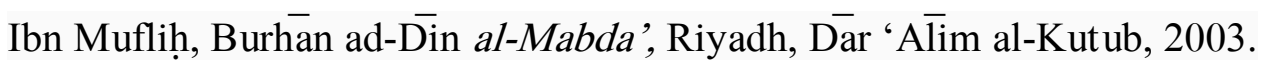

Ibn Qudamah, Muwafiq ad-Din 'Abd ar-Rahman al-Maqdisi, Sharh al-Kabīir, t.t, t.p, t.t. , al-Mugni, Damaskus, al-Mausu' ah al-'Arabuyah al-'Alimiyah, t.t. , al-Kā̄î̀ fi Fiqh al-Imām Aḥmad Ibn Hanbal, Beirut: Dāar al-Kutub al-'Ilmiyah, t.t.

Ibn Rushd, al-Andalusìi, Bidāyah al-Mujtahid wa Nihāyah al-Muqtasid, Jakarta, Dār alIhyā' al-Kutub al-'Arabiyah.

al-Jurjāini, Ali Ibn Muhammad as-Sayyid as-Shārif, Kitāb at-Ta’rifăt, t.t: Dār al-Irsyad, t.t.

al-Makki, Muhammad Nuruddin Banjar, Fiqh Darah Perempuan, Solo, Intermedia, 2002. Malike, Lissa dan Asmawati, Haid Membawa Berkah, Jakarta, Niaga Swadaya, 2010.

Misbah AB, Teori Praktis Seputar Haid, Gresik: ar-Rawḍah, 2010.

Muhadjir, Noeng, Metode Kualitatif, Yogyakarta, Rake Sarasin, 2000.

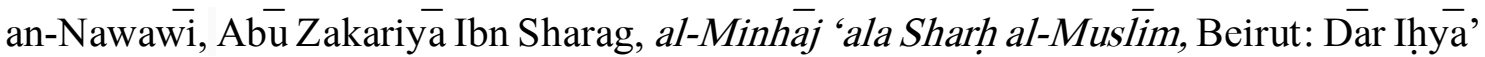
at-Turath al-'Arabi, $1392 \mathrm{H}$.

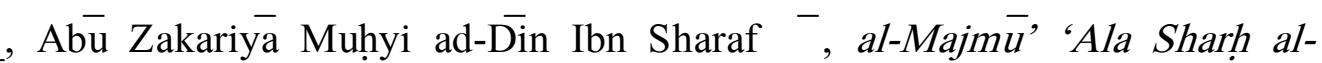
Muhhadhdhab, Damaskus, Dar al-Fikr, t.t.

Nuruddin, Muhammad Banjar al-Makki, Fiqh Darah Perempuan, Solo, Intermedia, 2002.

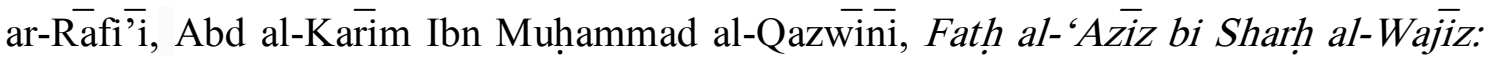
Sharh al-Kabir, t.t: t.p, t.t.

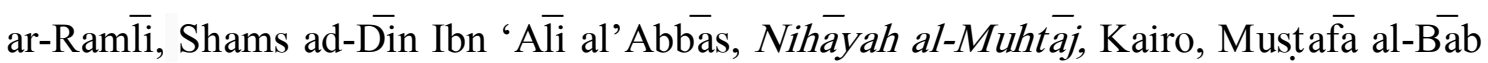
al-Halabi, 1938.

as-Sharbini, Muhammad Ibn Aḥmad al-Khațīb, Mugni al-Muḥtāj, Kairo, t.p, t.t.

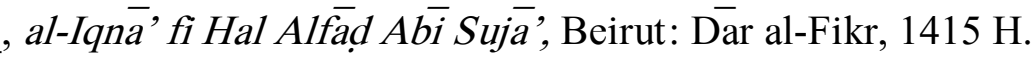

at-Tirkī, Muhșin, Ușūl Madhhab al-Imām Aḥmad, Riyadh: Maktabah ar-Riyāạ alHadithah, 1980.

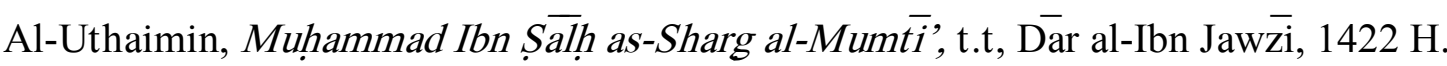


AL-'ADALAH: Jurnal Syariah dan Hukum Islam

e-ISSN: 2503-1473

Hal. 22-40

Vol. 1, No. 1, Maret 2016

'Uwaidah, Muhammad, Aḥmad Ibn Hanbal Imām Ahl as-Sunnah, Beirut, Dar al-Kuub al-'Ilmiyah, t.t.

Warson Munawwir, Aḥmad, al-Munawwir Kamus Arab - Indonesia, Surabaya: Pustaka Progresif, 1997.

Zuhri, Saifuddin, Haid dan Problematika Wanita, Mojokerto, Majmā' al-Bahrain, 2010. 